\title{
Towards Equity through Dairy Activity: Peoples Participation and Effective Implementation of IWMP in Rayalaseema Districts of Andhra Pradesh
}

\author{
P. V. R. M. Reddy ${ }^{1}$, B. Janardha Reddy ${ }^{2}$, B. V. Ramana Kumar ${ }^{3}$, \\ R. Jhansi Rani ${ }^{*}$ and Pullanna Vidyapogu ${ }^{5}$
}

${ }^{1}$ Director Watersheds, ${ }^{2}$ Joint Commissioner (watersheds) State Level Nodal Agency, Andhra Pradesh, ${ }^{3}$ Chief Executive Officer, ${ }^{4}$ Programme Manager, ${ }^{5}$ Consultant-Remote Sensing Instruments, Hyderabad, India

M/s. Remote Sensing Instruments, Plot No.7, Type-I, Industrial Estate, Kukatpally, Hyderabad, India

*Corresponding author

\section{A B S T R A C T}

Keywords

Livelihood, Collective action, Institutional mechanism, People's participation, Sustenance

Article Info

Accepted:

12 December 2020 Available Online: 10 January 2021
Dairy activity is one of the main staple economic sources and also a viable option for people in rural India especially small and marginal farmers based on the geophysical and ecological conditions. This can be seen at two levels; one is an economic source and the second a given asset. So far, it was viewed as an economic asset and symbol of social status based on who possess them. But the intervention of watershed programs across the country has brought livestock and dairy activity to reduce the income gaps among various social sections of the society. This has addressed through the livelihood component under IWMP and involved marginalized communities based on priority by providing milch animals. The crucial element for the successful implementation of dairy activity in the drought-hit region of Rayalaseema shows people's active participation through IWMP from various vantage points. This program introduced the dairy activity to lower-income groups predominantly by setting up objectives about various components in order to overcome persistent problems such as unemployment, less productivity, low rainfall, drought, and migration. Implementation of dairy activity has been yielding good results in improving the lives of landless, asset-less, marginal farmers, and women in rural areas.

\section{Introduction}

Dairy is a major livestock enterprise and has long history in India also enhanced dairy production through various programmes. For instance, 'White Revolution' achieved through a World Bank funded Operation Flood (OF) programme which was instrumental in enhancing milk production.
Most importantly, it is part of many people's daily lives in rural villages since ages where animal lives which are intertwined with human life.

Livelihood component under Integrated Watershed Management Programme (IWMP) intended to address the equity issue along with sustainability. So far in the watershed 
management or development programmes have been missed the equity issue since it heavily focused on productivity component and less emphasis had put on livelihoods component. Productivity largely confined to the agricultural households but not beyond them. So, livelihood component basically introduced through productivity focused activity but later it realized that the other sections of the society need to be consider such as agricultural labor, marginalized sections like land less, asset less communities, and more importantly women. IWMP has provided the provision to address these untouched aspects of overall watershed development through livelihoods component.

Livelihood component not only provides support for productivity-based activities but also off-farm activities. These are basically agriculture and allied activities especially dairy, fodder development, food process activities, nutrient management, livestock production and its sustenance. In this, dairy is the most activity where people adopted easily and seen as suitable survival economic option to lead better life. Again this time, the dairy activity not confined to only agricultural or farming community but to the marginalized sections of the society who were never practiced it for their livelihoods. This activity is seen as a sea change especially with the effective and innovative approach by the Project Implementing Agency (PIA) that is IWMP and people's active participation as a collective group. These two-way effective approaches towards the program objectives intended were realized through effectiveness in planning, eligibility criteria, funding, capacity building, and implementation of the project.

\section{Livelihood Improvement Guidelines}

Guidelines for improving lives of rural people in the watershed villages, IWMP has provided which were issued in 2008 and revised in 2011. In these guidelines, livelihood component has its own prominence in shaping the lives of rural people in adopting provisions provided under IWMP. These are not only played on the paper but very much in practice since the intensive efforts were paid throughout the program which reflected even after the project. This is where the study is going to talk on the evaluation impact after the project.

The livelihood component aimed at to maximize the utilization of potential generated by watershed activities and creation of sustainable livelihoods and enhanced incomes of households within the watershed area.

One of the main guiding principles is that to improve household income of landless / asset less households, people's participation and division of labour, access to information, knowledge, appropriate technologies and resources.

\section{Livelihood perspective under IWMP}

Livelihood component of IWMP is aimed to promote natural resource-based activities to enhance livelihood opportunities for the poor (SC/ST, landless, asset less, and women) in creating assets by investing to improve productivity and income. The guidelines also emphasized on improving household income, participation, division of labor, access to information, knowledge, appropriate technologies and resources by addressing issues of equity, gender, and transparency (Department of Land Resources 2011). To attain its aims, the livelihood component also had several stages of activities planned such as planning, mode of operation, eligibility, funding, capacity building, and implementation. Along with this, the component also has provision to production 
system and microenterprises based livelihood activities under IWMP. With this, they try to promote diversified production/farming systems by encouraging farmers to adopt and up-scale successful experiences of proven technologies integrated farming systems and improved farming practices for livelihood augmentation (Department of Land Resources 2011).

Dairy farming is an important source of subsidiary income to small / marginal and also agricultural laborers in rural India. Dairy activity is not involved with only milk production, but it also produces organic matter which uses in the fields to fertile soil for crops, livestock production, production of milk-based food items with nutrient protection, and employment it proves for small and marginal farmers and also landless labors. One more key factor for dairy activity success in rural areas is the involvement and participation of women who plays crucial role in the processes of dairy and livestock production. So far, this activity seen with the population that are associated with agriculture but now it has been spread across population who were never used to especially marginalized sections of the society. Involvement of marginalized sections in the dairy activity was minimal in the past but with the watershed intervention the activity included many people irrespective of their profession and social status. This is the step towards building an equitable society with economic stability.

\section{Approach}

Dairy activities in the watershed programme comprised as fodder (types, preparation, storage of dry fodder), breed of the cows and buffalos, nutrient food for livestock, animal health camps, milk extraction, chaff cutters for enhancing food efficiency, PSI activities undertaken, income and expenses,
Impact of watershed projects on population of livestock and milk production can be observed from number of projects, number of livestock population, production of milk before and after, and change in income.

The project anticipated results at improving the quantum and quantity of milk production, enhancing livelihoods among rural poor, better animal care with livestock production, women empowerment, better management of natural resources and sustainable development.

\section{Materials and Methods}

Impact evaluation has been conducted to determine the changes in socioeconomic conditions of the stakeholders especially on the activities of agricultural production, livestock production, dairy production, status of the natural resources, changes in crops and household income. To assess the impact among all the above, the selected watershed projects under IWMP have covered for the study from the four districts of Rayalaseema region. Secondary information related to the project is collected from project office, Watershed Computer Centers (WCC), concerned DPRs, government documents, books, articles, and other relevant records using a well-designed open-ended format for detecting changes.

In addition, the total households under each micro-watershed are selected on a random basis and surveyed for socio-economic changes as well as changes in land use, livestock production, dairy activity, and household income. Present values are compared with base values to determine the impacts over milk production. In addition, focus group discussions were held with stakeholders to capture qualitative information related to project implementation and its impact on dairy activity and its 
supplemented activities. In-depth individual case studies were also conducted in order to understand the effectiveness of project implementation and its impact on individual household income.

\section{Study area}

Four districts of Rayalaseema such as Anantapur, Chittoor, Kurnool, and YSR Kadapa are semi-arid and drought-prone in nature due to less rainfall. This region has given special focus by the watershed programs like, DDP, DPAP, and now IWMP since decades.

\section{Results and Discussion}

The major activities of watersheds under Integrated Watershed Management Program (IWMP) proposed were production based activities like water storage through constructions of water harvesting structures in that application of micro nutrients such as saline alkali draining salts, application of gypsum and nitrogen as per soil test reports considered to identify it as suitable location for taking up intensive cultivation with agronomical practices like contour farming, strip cropping, mulching tillage practices. Constructions of ponds are done by removing soil and allowing water to fill in the dugout area. Most of the water comes from ground water seepage or natural springs. Second is livelihood-based activities which are extension to production based activities especially agricultural allied activities such as rearing of goats, buffalos, and cows, fodder development, vermi compost, milk production and distribution, livestock production, petty businesses (small provision shops, stitching machines and selling vegetables), and small enterprises (grinding machines). Dairy activities such as milk production and distribution are one of the predominant occupations among all the livelihood activities in the study area of Rayalaseema region since it is part of most of the rural lives and familiar activity. So, it is easy to adopt and make lives out of it. These activities were carried out in the watershed villages through various interventions by IWMP under livelihood component. The details of the activities can be observed and understand from the below tables with analysis.

The selected area for the study covers 80 projects from the four districts of Rayalaseema such as Anantapur, Chittoor, Kurnool, and YSR Kadapa for the period of 2012 to 2019. As part of the program, the total net treated area is $3,45,983$ ha. by covering 346 villages and 1212 habitations.

Guidelines of livelihoods under IWMP have provided special provisions against the regular watershed activities in order to address equity issues and include marginalized sections of the society whose livelihoods are mostly agricultural labor and daily wage. This has come with the proper planning and execution with people's active participation. So, the activities started with pre-project preparation to implementation of the project in intensive manner. In order to achieve the objectives of the programme and its impact, before and after / with and without intervention of watershed activities considered. The approach followed all along in the program implemented through;

\section{Scheme of functionality}

Planning - Pre-project analysis, identification of the study site and beneficiaries, detailed project report of activities to be taken, promotion of convergence, action plan

Eligibility - $\quad$ Individual land holders/landowners, small / marginal farmers, women (single headed / farmer and women in SHGs, SC/ST farmers and daily wage 
labours.

Funding - proposed for the project under each activity for beneficiaries under productivity-based activities and entrepreneurs.

Capacity Building - landholders / owners

Implementation of the project - With the agreed action plan by WC, VO, SHG, WDT with the SLNA authorities

Initially, the dairy activity under livelihood component followed with the livestock maintenance and production in the project area with all the beneficiaries. This can be understood from the status of livestock before and after the project with identifying difference and percentage of it from 20112012 to $2019-2020$.

Livestock population in the watershed villages consists largely as cows and buffalos. Before and after the project, the total number of cows and buffalos in the four districts increased from 65,499 to 36,301 to 82,374 to 59,496 . The difference among cows marked as 16,875 and buffalos are 23,195 with the percentage of 234 to 273 . This denotes that the increase in the number of cows and buffalos which is also reflects the status of milk production, its distribution, and fodder development. Milk production activity was carried out with the supporting activities such as forging fodder, distributing fodder cutters, seeds, fertilizers, planning, awareness, training, and participation. The activities that have taken in throughout the project are follows as;

Milk production in the study area of four districts of Rayalaseema shows improvement supportive activities with action plan. These activities not confined to providing them financial help and handover supplements under the program but started with proper planning by taking the status of before status of the project area that follows as;

\section{Pre-project approach}

Officials from the Program Implementing Agency (PIA) approached the selected watershed villages to get the status of various variables in relation to production based and livelihood-based activities before launching the program. These were observed especially in terms of the watershed upstream and downstream flows, ground water table, precipitation level, soil erosion and quality, agricultural practices and allied activities, and income of levels of households.

\section{Preparation of Detailed Project Report}

Based on the pre-project learning on the ground, the PIA moved to prepare a comprehensive detailed project report with all the stakeholders. This report includes the households who have landholdings and landless in order to address production based and livelihood-based activities in the selected watershed villages. The report proposed activities that can work for all the sections of the society in the village. So, IWMP provided livelihoods component has added new provision under guidelines is production system and microenterprises with financial assistance along with regular livelihoods activities.

The effective element in this project is action plan in implementation with collective action and participation. This led to realize the detailed project report in addressing the main objectives of the project. The success of the DPRs is always depends on the adoptability of activities in accordance with the changing situations on the ground in the given stipulated time of the project. 
Identifying activities in the respective watershed project areas

Activities identified based on the detailed study of pre-project analysis and preparation of comprehensive action plan. These activities were addressed both agricultural and allied activities, and livelihood activities. Along with construction of check dams, farm ponds, trench cum nala bunds, plantation, and seed distribution, livelihoods activities like milk production, fodder development activities carried out. The identified activities especially under livelihood activities are addressed equity issues among marginalized sections of the society which was a missing element in the inclusive watershed development.

\section{Awareness activities}

In order to address equity issues in the watershed management program awareness plays a key role in the success of the program. Awareness activities have taken on the proposed activities under livelihoods component. The awareness activities took in the form of workshops, regular meetings, and interactions. Workshops are on activities are about planning and execution in practical terms. Meetings are basically to get the opinion by group and individual wise in order to fill the confidence and stage fear to raise voice. So far, this approach has been successful because of people's active participation. There were also informal interactions between all the stakeholders based on the activities have taken up.

\section{Selection of beneficiaries for the activities}

Beneficiary selection followed the approach that was intended in the basic guidelines of the IWMP where equity is the major concern in this program. Issue of equity evolved with not only individual income level but also social status in the given social strata of the society. Traditionally, our society divided based on caste, profession, class, language, nativity, region, place, gender, and ethnicity. Based on this variety of diversity and disparity at many levels bringing equality is a difficult and complex task.

Selection for the production-based activities was based on landholdings of households and livelihoods are based income level and also social status. The activity of dairy supported with easy adoptability of beneficiaries with financial support and skill development providing new supplements through training. So, the beneficiary economic status and income level peaks their involvement in the activity and adoptable mechanism provided by the PIA.

\section{Training programs}

Training programs have been conducted extensively based on action plan prepared for the proposed activity. Trainings have provided especially in livestock production and developing fodder. To do this animal health camps have facilitated awareness on the breeds of livestock and maintenance of it. For forging fodder, new implements like cutters provided in order to maintain the growth of fodder. Fodder quality and production played a key role in forging livestock like cows and buffalos. This further led in reaping more milk for longer periods of time.

\section{Financial assistance}

Funding was provided under two main components such as production based and livelihoods. Again, under livelihoods there are two provisions one is livelihood and enterprise activities. Funding provided separately for these two provisions with different procedure since activities divided based on the group and individual. 


\section{Capacity building}

Individual abilities improved under the program through training at various levels. the abilities were initially assessed through awareness camps and trainings in the proposed activities. Under livelihoods, there are mainly activities taken up towards livestock, milk production, and enterprising. In this, maintenance of breeds of livestock and harvesting various variety of plants for fodder development considered. More importantly, enterprising activities for individual development focused and followed the same during the program period.

\section{Execution of the project}

Project execution started with the pre-project assessment to planning, funding, and capacity building. The main activity in the project successfully done is dairy activity which has been seen a key element for change in the lives of rural people in the proposed watershed villages. Dairy activity is not a new area for people to adopt and carry it for their livelihoods. Dairy activity consists of livestock and milk production. For milk production, fodder development activity taken up immensely.

\section{Preparation of Silage}

Silage is prepared in a pit with $8 * 5 * 25$ dimensions and bottom is covered with plastic sheet. It can be fed to cattle $20 \mathrm{kgs} /$ day/animal. Below 65-70\% moisture presence is recommended. Care must be given while cutting green grass that it should be grown fully. Before feeding fodder to animals it is made into small pieces for proper digestion.

\section{Storage of Dry Fodder}

Major crops of dry fodder are paddy, corn, and maize. Volume of nutrients is lower in dry fodder. There are no vitamins, proteins, or minerals. Fiber content helps to digest effectively. The addition of urea and fermentation improves fodder quality.

\section{Best Practices Adapted for Strengthening Dairy at Village Level}

Selection of Best Cattle Breeds

Cow and buffalo breeds are important for good milk yield

Minimum milk is 10 liters for cow and buffalo 8 liters per day

It should give milk twice or thrice a day

Importance should be given to body structure, weight and skin

\section{Mineral Mixture and Fodder}

It is important to select high nutrient food for cattle in the form of green and dry fodder, mineral mixture

Napeir grass lives for 3-4 years and ensures continuous fodder supply

Inter cropping with Subabul and Avesha in fodder crop helps to harness

more quantity of feed from same piece of land It is advised to avoid feeding alone green fodder or dry fodder

Silage helps to store green fodder for long periods

Dry fodder is treated with urea for storing

The animal population details of four districts of Rayalaseema region given in the above tables. Population of cows and buffalos shows significant increase in the districts it was not the main activity. From the beginning Chittor district marked is high in the livestock and milk production where the other districts are not seen as much with dairy and related activities. Kurnool districts denote high in the livestock production and also in the milk production. Anantapur and YSR Kadapa districts are following Kurnool. Chittoor 
district is as usual shows high in the production of livestock and milk but due to watershed activity under livelihoods Kurnool and Anantapur districts are also showed significant change in the dairy activity. This denotes that the focused areas for improving livelihoods of people in the semi-arid region of Rayalaseema. There was not much improvement in livestock and milk production at Chittoor district since it is a pro-active activity.

\section{Artificial insemination}

In spite of the large number of livestock, production is less hence increase in productivity across all species, is a major challenge. To reduce production of unproductive cattle and improve the productivity by improving the breeds by breeding management following activities carried out

Castration

Artificial insemination

Distribution of superior Breeding bulls for use in Cattle and Buffalo

Vaccination Camp

The target is one calf per year

Monitoring by veterinary doctor

Birth rate should be high with minimum gap between two deliveries

Proper care is given to new born

New born are fed with milk and leaves

Diseased or ill animals are kept away from healthy animals

Animal shed should be cleaned with disinfectants

\section{Animal health camps}

The basic objective of conducting the camp is to gain an understanding of the general livestock health status and management practices and prevalent diseases/problems in the area so that livestock related interventions could be taken up systematically.

The camps organized by local veterinary assistant surgeon and their staff. Outside experts invited as per the need. Dairy Cattle, Buffalo treated for different diseases/problems. Free veterinary camps would be conducted by the Department of Animal Husbandry in the dairy intensive Gram panchayats of the state, to enable farmers and poor people to get treatment for their dairy cattle and buffalo.

\section{Milk extraction}

The method of milking is performed manually and by machine

Animal cleanliness is necessary before milking

Last milk has a high fat content and less bacteria

To preserve color, taste and smell, silage feeding should be avoided before milking

\section{Chaff Cutters for Enhancing Feed Efficiency}

Chaff cutter ensuring proper digestion and is an important machine for ensuring enhanced feed efficiency. Chaff cutter is an importance mechanical device in animal husbandry. The feed provided this way helps in proper digestion by the animal. The milk production is directly link to the palatability of feed that is provided to the animal. The cut pieces of straw/hay done by chaff cutter are used in feed mixture.

Milk production among four districts of Rayalaseema denotes that considerable increase even the districts were not known for dairy activity. Chittoor district shows more production than other and other districts like Kurnool, Anantapur, and YSR Kadapa follows. The significant feature in the milk production is that the districts like Kurnool 
and Anantapur showed considerable change since it was not seen dairy activity much among landless households and daily wage labor.

\section{PSI Activities Carried out During Project Implementation}

Health coverage

Fertility Camps

Nutritional Support

Feed Supply to Pregnant Milch Animals during last 100 days of pregnancy
Feed Supply to AI born true to type calves Graded murrah calves

Cross Breed calves

Mineral mixture to milch animals and calves

Establishment of Travices

Electronic milk testing units

Community chaff cutters

Construction of drinking water troughs

(EPA/NRM)

Milking Machine

Milk cans, Chains

Support for perinial fodder plot

NADEP Comost Pits

Table.1 Batch - III Watershed Project Details

\begin{tabular}{|c|c|c|c|c|c|}
\hline S. No & $\begin{array}{c}\text { Name of the } \\
\text { district }\end{array}$ & $\begin{array}{c}\text { No of projects in } \\
\text { Batch-III }\end{array}$ & $\begin{array}{c}\text { No of MWS } \\
\text { villages }\end{array}$ & $\begin{array}{c}\text { No of } \\
\text { Habitations }\end{array}$ & $\begin{array}{c}\text { Net Treatment } \\
\text { Area (Ha) }\end{array}$ \\
\hline $\mathbf{1}$ & Anantapur & 29 & 127 & 324 & 124506 \\
\hline $\mathbf{2}$ & Chittoor & 20 & 105 & 605 & 82687 \\
\hline $\mathbf{3}$ & Kurnool & 22 & 76 & 109 & 98900 \\
\hline $\mathbf{4}$ & YSR Kadapa & 9 & 38 & 174 & 39890 \\
\hline & Total & $\mathbf{8 0}$ & $\mathbf{3 4 6}$ & $\mathbf{1 2 1 2}$ & $\mathbf{3 4 5 9 8 3}$ \\
\hline
\end{tabular}

Table.2 Animal Population before and after the Watershed Intervention - Cows

\begin{tabular}{|c|c|c|c|c|c|}
\hline S. No & $\begin{array}{c}\text { Name of the } \\
\text { district }\end{array}$ & $\begin{array}{c}\text { Before the } \\
\text { project } \\
\mathbf{2 0 1 1 - 2 0 1 2}\end{array}$ & $\begin{array}{c}\text { After the project } \\
\mathbf{2 0 1 9 - 2 0 2 0}\end{array}$ & Difference & $\begin{array}{c}\text { Change of } \\
\text { percentage }\end{array}$ \\
\hline $\mathbf{1}$ & Anantapur & 11383 & 12971 & 1588 & 14 \\
\hline $\mathbf{2}$ & Chittoor & 39497 & 39960 & 463 & 1 \\
\hline $\mathbf{3}$ & Kurnool & 13259 & 26458 & 13199 & 100 \\
\hline $\mathbf{4}$ & YSR Kadapa & 1360 & 2985 & 1635 & 119 \\
\hline & Total & $\mathbf{6 5 4 9 9}$ & $\mathbf{8 2 3 7 4}$ & $\mathbf{1 6 8 7 5}$ & $\mathbf{2 3 4}$ \\
\hline
\end{tabular}

Table.3 Animal Population before and after the Watershed Intervention - Buffalos

\begin{tabular}{|c|c|c|c|c|c|}
\hline S. No & $\begin{array}{c}\text { Name of the } \\
\text { district }\end{array}$ & $\begin{array}{c}\text { Before the project } \\
\mathbf{2 0 1 1 - 2 0 2 0}\end{array}$ & $\begin{array}{c}\text { After the project } \\
\mathbf{2 0 1 9 - 2 0 2 0}\end{array}$ & Difference & $\begin{array}{c}\text { Change of } \\
\text { percentage }\end{array}$ \\
\hline $\mathbf{1}$ & Anantapur & 11747 & 13411 & 1664 & 14 \\
\hline $\mathbf{2}$ & Chittoor & 1612 & 3229 & 1617 & 100 \\
\hline $\mathbf{3}$ & Kurnool & 15757 & 31434 & 15677 & 99 \\
\hline $\mathbf{4}$ & YSR Kadapa & 7185 & 11422 & 4237 & 59 \\
\hline & Total & $\mathbf{3 6 3 0 1}$ & $\mathbf{5 9 4 9 6}$ & $\mathbf{2 3 1 9 5}$ & $\mathbf{2 7 3}$ \\
\hline
\end{tabular}


Table.4 District-wise Milk Production before and after the Watershed Intervention

\begin{tabular}{|c|l|c|c|c|c|}
\hline S. No & $\begin{array}{c}\text { Name of the } \\
\text { District }\end{array}$ & $\begin{array}{c}\text { Before the project } \\
\text { 2011-12 (thousand } \\
\text { liters per annum) }\end{array}$ & $\begin{array}{c}\text { After the project } \\
\mathbf{2 0 1 1 - 1 2} \text { (thousand } \\
\text { liters per annum) }\end{array}$ & Difference & Percentage \\
\hline $\mathbf{1}$ & Anantapur & 5617 & 13016 & 7399 & 132 \\
\hline $\mathbf{2}$ & Chittoor & 29631 & 38349 & 8718 & 29 \\
\hline $\mathbf{3}$ & Kurnool & 7339 & 16301 & 8962 & 122 \\
\hline $\mathbf{4}$ & YSR Kadapa & 5191 & 14153 & 8962 & 173 \\
\hline & Total & $\mathbf{4 9 8 8 4}$ & $\mathbf{8 4 8 1 7}$ & $\mathbf{3 4 9 3 3}$ & $\mathbf{7 0}$ \\
\hline
\end{tabular}

Table.5 Types of Green Grass Grown for Fodder Production

\begin{tabular}{|c|c|c|c|c|c|}
\hline $\begin{array}{l}\text { Name of the } \\
\text { Grass }\end{array}$ & Suitable Climate & $\begin{array}{c}\text { Yield / } \\
\text { Annum }\end{array}$ & Season & $\begin{array}{l}\text { Yield acre (in } \\
\text { Tonnes) }\end{array}$ & Remarks \\
\hline S S G Jowar & Low rainfall & $3-4$ & Jan-Aug & $18-20$ & $\begin{array}{l}\text { Suitable in all } \\
\text { types of soils }\end{array}$ \\
\hline Corn & Rainfed & 1 & Annual & $16-20$ & Suitable for silage \\
\hline Bajra & Low rainfall & 2 & Jan-Aug & $12-14$ & $\begin{array}{l}\text { High protein } \\
\text { content }\end{array}$ \\
\hline $\begin{array}{l}\text { Hybrid } \\
\text { Napeir }\end{array}$ & Irrigated Area & $8-10$ & June-July & $40-70$ & Hybrid Variety \\
\hline Para Grass & Water logging areas & $8-10$ & Annual & $40-60$ & $\begin{array}{c}\text { Lives for 3-4 } \\
\text { years }\end{array}$ \\
\hline Guini Grass & Sandy soils & $4-5$ & Winter season & $30-40$ & $\begin{array}{l}\text { Can grow in shadow } \\
\text { conditions }\end{array}$ \\
\hline Philisesara & Black soils & 2 & Aug-Jan & $10-12$ & $\begin{array}{l}\text { Can be grown } \\
\text { after harvesting } \\
\text { paddy in field }\end{array}$ \\
\hline Loosers & All fertile lands & $6-7$ & Oct-Nov & $24-30$ & $\begin{array}{l}\text { Suitable for } \\
\text { intercropping }\end{array}$ \\
\hline Alasanda & $\begin{array}{l}\text { Moisture retaining } \\
\text { soils }\end{array}$ & $2-4$ & Jan-Aug & $8-10$ & $\begin{array}{l}\text { Suitable for } \\
\text { intercropping }\end{array}$ \\
\hline Janumu & $\begin{array}{l}\text { Sandy soils, in soils } \\
\text { after harvesting } \\
\text { paddy }\end{array}$ & & $\begin{array}{l}\text { Feb-Mar } \\
\text { Oct-Nov }\end{array}$ & $10-12$ & $\begin{array}{l}\text { Suitable for } \\
\text { intercropping }\end{array}$ \\
\hline Stylo & $\begin{array}{l}\text { Waste lands, light } \\
\text { soils, sandy soils and } \\
\text { low rainfall areas }\end{array}$ & 5 & $\begin{array}{l}\text { May, June and } \\
\text { July }\end{array}$ & $8-10$ & $\begin{array}{l}\text { Can be grown } \\
\text { along the field } \\
\text { bunds }\end{array}$ \\
\hline Subabul & $\begin{array}{c}\text { Sandy soils and } \\
\text { normal soils }\end{array}$ & $\begin{array}{l}\text { One } \\
\text { plant }- \\
2.5 \mathrm{Kg} \\
\text { grass }\end{array}$ & Annual plant & $\begin{array}{c}250-300 \\
\text { plants gives } 10 \\
-12 \text { Kgs per } \\
\text { day }\end{array}$ & $\begin{array}{c}\text { Strong root } \\
\text { system, resistivity } \\
\text { towards low/lack } \\
\text { of rainfall }\end{array}$ \\
\hline Avisha & Wet and dry lands & 6 & Annual plant & $15-20$ & \\
\hline
\end{tabular}


Table.6 Species of Cows and Buffalos

\begin{tabular}{|c|c|}
\hline Buffalos Species & Cow Species \\
\hline Murra & Kankreze \\
\hline Mohsena & Red Sindhi \\
\hline Jhafrabadi & Gir \\
\hline Soorthi & Shahiwal \\
\hline Neeli & Dimoni \\
\hline Raavi & Tarparker \\
\hline & Ongole \\
\hline & Haryana \\
\hline & Jesrsy \\
\hline & H. F \\
\hline
\end{tabular}

Graph.1 Animal Population before and after the Watershed Intervention - Cows

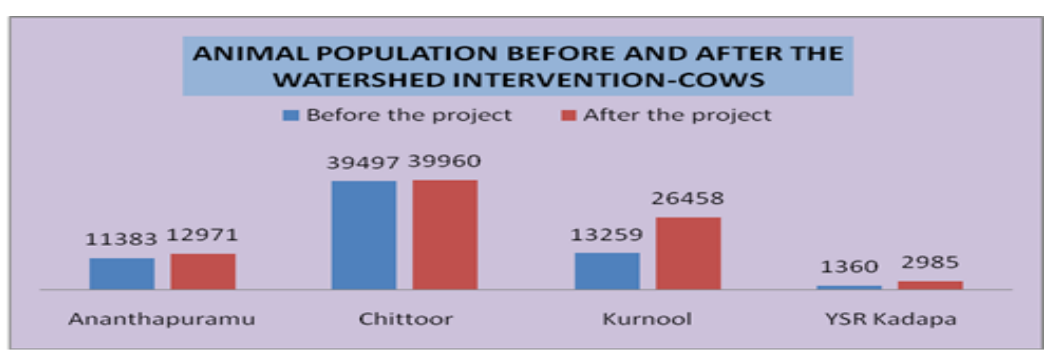

Graph.2 Animal Population before and after the Watershed Intervention - Buffalos

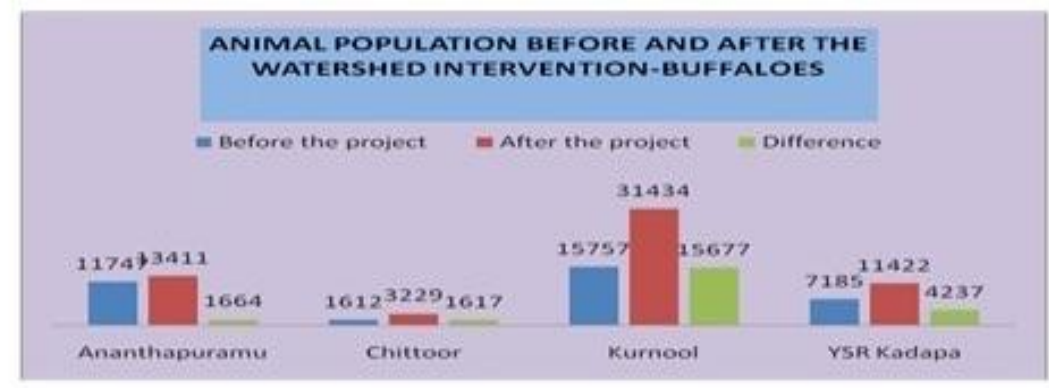

Graph.3 Milk Production among Four Districts of Rayalaseema

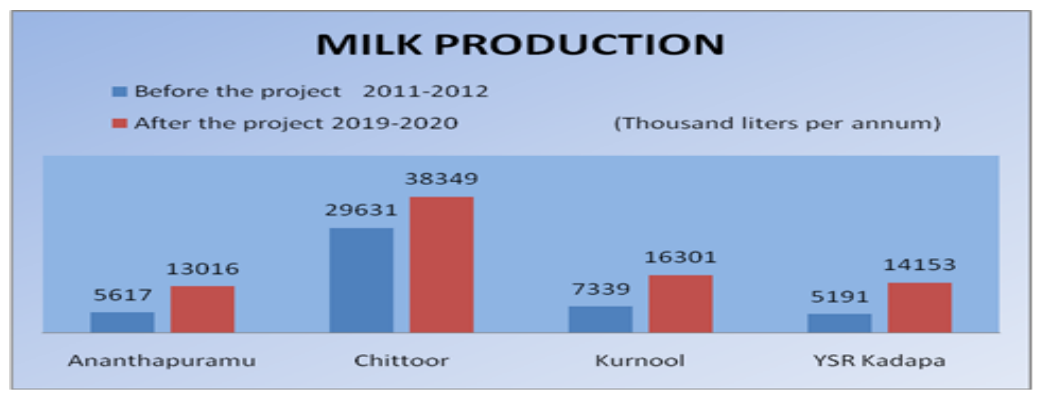



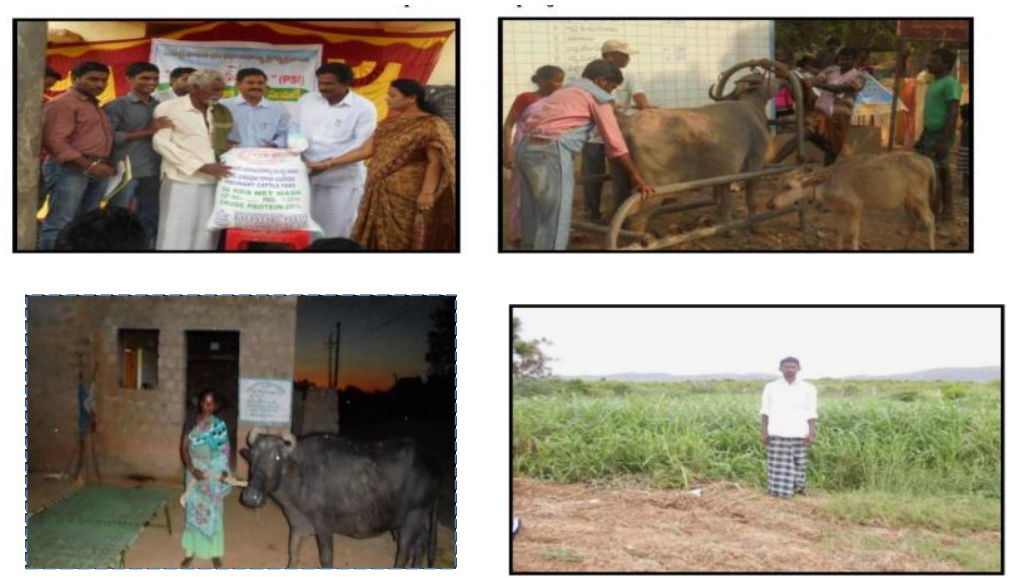

Overall development of marginal and landless sections of the society not entirely depends on the dairy activity but there are other activities which have supplemented to their overall well-being. But dairy plays a crucial role in the economic security since they are well aware, skilled, and familiar to the activity. This familiarity cannot be seen as their special performance in the activity in order to secure livelihoods in more sustainable manner. But improvements in the dairy activity can be considered as an add-on story to their economic development. The story contained livestock and allied activities through action plan such as fodder development, provision of tool kits, quality improvement measures, and mission mode operation with specific focused activities. So, it is the culmination of dairy and related activities.

The government watershed programs in the drought-prone and semi-arid regions in a way promised them through by engaging them throughout the program and make them to realize the benefits in doing so. An evaluation study of Vidharbha region of Maharashtra by G. L. Bagdi and R. S. Kurothe denoting that the active participation of stakeholders has come from motivation from one to the other in the soil and water conservation not only at planning and implementation stage but also maintaining stage in order to attain sustainable agricultural production (G. L. Bagdi and R. S. Kurothe 2014). This further

led to take up intensive priority-based activities under watershed programs across the country. As a result, special provisional guidelines issued during 1994 and 2008 and the revised guidelines in 2011 which have brought series of activities not only agricultural production but also added special focus on livelihoods. This effort by the government and agencies attracted and encouraged different sections of the society in providing them space to participate and act accordingly. In the initial sages the outcomes of the projects brought significant gaps and dynamism that plays at various level in watershed programs. For instance, the study by Badal et al., emphasized on the institutional effectiveness is the key factor in guarantying people's involvement in watershed programs found that there is a considerable gap between participation and off-farm activities and suggested that there is need of constant engagement in activities in more participatory way between PIA and beneficiaries (Badal et al., 2006).

To address the gaps and dynamism in watershed programs, IWMP initiated programs on priority-based in the semi-arid and drought-prone areas. Rayalaseema of Andhra Pradesh is one of the sei-arid regions which have less rainfall and low agricultural production and allied activities. Rayalaseema region consists of four districts such as Anantapur, Chittoor, Kurnool, and YSR 
Kadapa districts which are basically depended largely on agricultural activity. These four districts also have high migration to not only inter-state but also intra-state and intercontinental with seasonal and unseasonal. Though there were efforts to curb migration not many results yielded but there is a hope rising from the watershed activities which have not only addressing production-based activities but livelihood-based activities in the region. This can be observed in the dairy activity which is showing good results with stable income even after the program. This was nurtured through institutional mechanism with people's active participation.

In this study participation of people found as a key factor for the success of dairy activity. This can be understood from the theoretical explanation based on the nature and context of the study area since participation does not provide any static definitions.

This varies from one to the other study areas based on its nature and determinations of participants. Cohen and Uphoffs expressed their opinion as the success of rural development perspective depends upon the kinds and dimensions of participation that takes place with the questions such as what, who, how and why? (Cohen and Uphoffs 1980). This gives us the sense on the kinds of participation that takes place based on what people determined to attain through any government given development programs. For instance, one of the crucial elements of women empowerment in the watershed activities depends on the nature and extent of collective participation which comes from the awareness about the watershed operations (Sreedevi et al., 2007). In this view, public participation has become an important tool in the public policy-making in 2000's onwards. The key theoretical concerns suggested by Kathryn S. Quick and John M. Bryson are legitimacy, inclusion and diversity, expertise knowledge and challenges in designing public participation which have to negotiate in all contexts within the democratic processes since governance is intact with public agencies, officials and public (Quick, Kathryn S. and John M. Bryson 2016).

With the above conceptual explanation, the study gives us sense on the 'collective action is public' where collectivity involved through democratic processes in order to attain equitable society through economic benefits which promises in improving the social status and imagery. This has been realized through the activities of IWMP especially special provisions under livelihoods component with its innovative and effective efforts in not only policy and planning but in implementation and practice in the semi-arid regions like Rayalaseema of Andhra Pradesh.

In conclusion based on the analysis above, success of the dairy activity of course depends on the people's active participation but the important aspect active in participation is the key factor to understand the success of any kind. All the activities under livelihood component have implemented through the plans laid out by conducting workshops and meetings as part of Detailed Project Report (DPR) in accordance with the action plan. The effectiveness has come through the planned activities by PIA with the public whose determination is to achieve equitable development of all the stakeholders. This can be seen raise in their household income, employment, improvement of abilities, awareness about various processes in the activities and knowledge about sustaining them in the long run. With all these, the study revealed that there is raise in number of animals (cows and buffalos) and production of milk which is evident as significant increase in comparison to the before situation. These have been resulting in contributing to their social status, individual ability, 
economic stability and to care for the surrounding environment. In rural areas of Andhra Pradesh having livestock is also a symbol of social status since everyone cannot have this. So, though there are various dynamics involved in the processes of dairy activities, determination to build an equitable society through effective governance with people's participation is possible.

\section{References}

Badal, P.S., Kumar, P. and Bisaria, G., 2006. Dimensions and determinants of peoples' participation in watershed development programmes in Rajasthan. Agricultural Economics Research Review, 19(347-201616762), pp.57-70.

Bagdi, G.L. and Kurothe, R.S., 2014. People's participation in watershed management programmes: Evaluation study of Vidarbha region of Maharashtra in India. International soil and water conservation research, 2(3), pp.57-66.

Cohen, J.M. and Uphoff, N.T., 1980. Participation's place in rural development: seeking clarity through specificity. World development, 8(3), pp.213-235.

Department of Land Resources. 2011. Ministry of Rural Development. Broad Guidelines for the Livelihood Activities for the Landless/Asset less Households under IWMP. New Delhi.

Quick, K.S. and Bryson, J.M., 2016. Public participation. In Handbook on theories of governance. Edward Elgar Publishing.

Sreedevi, T.K., Wani, S.P. and Nageswara Rao, V., 2007. Empowerment of women for equitable participation in watershed management for improved livelihoods and sustainable development: an analytical study.

\section{How to cite this article:}

Reddy, P. V. R. M., B. Janardha Reddy, B. V. Ramana Kumar, R. Jhansi Rani and Pullanna Vidyapogu. 2021. Towards Equity through Dairy Activity: Peoples Participation and Effective Implementation of IWMP in Rayalaseema Districts of Andhra Pradesh. Int.J.Curr.Microbiol.App.Sci. 10(01): 879-892. doi: https://doi.org/10.20546/ijcmas.2021.1001.106 